\title{
OCENA POTENCJAŁU WIEDZY I INNOWACYJNOŚCI SIECI MIĘDZYORGANIZACYJNYCH W ŚWIETLE BADAŃ POLSKICH KLASTRÓW
}

DOI: 10.33141/po.2019.11.04

\section{Beata Barczak}

\section{Wprowadzenie}

W

e współczesnym złożonym i coraz lepiej skomunikowanym świecie dostrzega się konieczność kooperacji podmiotów o różnych uzupełniających się zasobach i kompetencjach. Organizacja, aby była w pełni konkurencyjna na globalnym i lokalnym rynku, powinna posiadać i absorbować odpowiednią wiedzę oraz umieć posiadaną wiedzę wykorzystać. Również w obszarze kształtowania innowacyjności postuluje się potrzebę wzmacniania współpracy. Zarządzanie wiedzą i innowacyjność szczególnie ważne są w przypadku organizacji sieciowych, które budują swój potencjał poprzez

odpowiednie wykorzystanie zasobów materialnych i niematerialnych oraz doskonalą proces interaktywnego uczenia się. Kluczowym zadaniem dla zarządzających siecią jest stymulowanie przepływu wiedzy pomiędzy różnymi podmiotami. Polepszenie przepływu sprzyja rozprzestrzenianiu się wiedzy, a stymulowanie chęci dzielenia się wiedzą wpływa na poziom innowacyjności.

Przedmiotem badań w niniejszym artykule jest potencjał wiedzy i innowacyjności sieci międzyorganizacyjnych, który należy rozumieć jako całokształt czynników wpływających na możliwość skutecznego realizowania 
przedsięwzięć o charakterze innowacyjnym. Stanowi on zbiór wzajemnie powiązanych elementów zasobów, który dzięki wykonywanej pracy przekształcony zostanie w nowy stan rzeczy - dzięki możliwościom konkretnych środków i sił tworzenia nowych wartości. Efektywność takich działań jest jedną z najistotniejszych determinant kształtowania konkurencyjności sieci. Współczesne podejście do problematyki innowacyjności i wiedzy przekłada obserwacje o nieliniowości i sieciowości procesu innowacyjnego na funkcjonowanie gospodarki. Koncepcja ta postrzega gospodarkę jako sieć wzajemnie powiązanych podmiotów gospodarczych i instytucji warunkującą zajście synergicznych efektów współpracy. Dlatego też poza instytucjami generującymi wiedzę i innowacje, jak przedsiębiorstwa, jednostki badawczo-rozwojowe czy instytucje pośredniczące $\mathrm{w}$ transferze innowacji, dostrzega ona znaczenie różnorakich interakcji zachodzących między nimi (Jasiński i in. , 2019; Garncarczyk, 2014; Jasiński, 2014).

Dynamika współczesnej gospodarki powoduje, iż szczególnego znaczenia nabiera umiejętność pomiaru i analizy szeroko pojętej innowacyjności sieci i aspektów związanych $\mathrm{z}$ wykorzystaniem, przepływem i wymianą wiedzy $\mathrm{w}$ ramach sieci. Powodowane jest to przede wszystkim faktem, iż duża część czynników istotnie wpływających na zdolności innowacyjne sieci ma trudno mierzalny czy też niekwantyfikowany charakter, co utrudnia precyzyjną analizę i ocenę tej problematyki. Ocena innowacyjności i zarządzania wiedzą stanowi jedno $\mathrm{z}$ ważniejszych wyzwań praktyków i teoretyków zajmujących się tą problematyką i problematyką sieci.

Punkt wyjścia rozważań stanowi założenie, że potencjał wiedzy i innowacyjności jest jedną z głównych determinant rozwoju i efektywności sieci międzyorganizacyjnych. W artykule przyjęto tezę, że dla oceny potencjału wiedzy i innowacyjności korzystne jest zastosowanie podejścia wielowymiarowego, w którym $\mathrm{w}$ ramach poszczególnych wymiarów analizuje się różnorodne kryteria oceny. Wykorzystanie tego podejścia stwarza możliwość kompleksowej oceny potencjału wiedzy i innowacyjności sieci.

Celem artykułu jest opracowanie koncepcji oceny potencjału wiedzy i innowacyjności sieci międzyorganizacyjnych. Przedstawiono autorską metodę oceny potencjału wiedzy i innowacyjności, ze wskazaniem kryteriów i wzorców oceny, a także dokonano przeglądu podejść i koncepcji oceny potencjału wiedzy i innowacyjności opisywanych w literaturze przedmiotu. Przegląd literatury przedmiotu pozwolił na zidentyfikowanie luki badawczej $\mathrm{w}$ zakresie metod pomiaru potencjału wiedzy i innowacyjności, w tym głównie w zakresie kryteriów jego oceny ${ }^{1}$.

Punktem wyjścia do badań był ogólny model oceny (Stabryła, 2016; Barczak, 2016), zaś w szczególności zastosowano wielokryterialną ocenę agregatową (Stabryła, 2011; 2016; Szwabowski, Deszcz, 2001), której istotą jest ustalenie syntetycznej wartości stanu organizacyjnego i funkcjonowania organizacji, na podstawie scalenia pojedynczych kryteriów oceny.

\section{Specyfika struktur klastrowych}

W iększość autorów podkreśla, w różnej formie, że klaster to skupisko (grupa) podmiotów (na ogół są to podmioty gospodarcze), działające w ramach jednego sektora (podobnych sektorów), które znajdują się w bliskim sąsiedztwie geograficznym (jednej przestrzeni geograficznej) i które ze sobą ściśle współpracują. Ponadto klastry dają możliwość kreowania efektu synergii, kooperując na tych samych zasadach rynkowych, współpracując i kreując wartość w ramach łańcucha dostaw (Porter, 2001).

$\mathrm{W}$ aspekcie ekonomicznym słowo klaster po raz pierwszy zostało użyte przez M.E. Portera (2001). Porterowskie podejście do definicji klastra, które w literaturze jest uznawane za najlepiej oddające charakter tego zjawiska, a przez to najczęściej cytowane, przedstawia klastry jako geograficzne skupiska wzajemnie powiązanych firm, wyspecjalizowanych dostawców, jednostek świadczących usługi, firm działających w pokrewnych sektorach i związanych z nimi instytucji (na przykład uniwersytetów, jednostek normalizacyjnych i stowarzyszeń branżowych) w poszczególnych dziedzinach, konkurujących między sobą, ale także współpracujących. Obok klasycznej już definicji M.E. Portera w literaturze przedmiotu funkcjonuje wiele innych definicji klastra. Większość z nich za główne wyznaczniki klastra uznaje trzy podstawowe czynniki: (1) koncentrację na określonym obszarze współzależnych przedsiębiorstw działających w tym samym bądź pokrewnych sektorach przemysłu lub usług (OECD, 2000; Rosenfeld, 1997), (2) interakcje i funkcjonalne powiązania pomiędzy firmami (Doeringer, Terkla, 1995), (3) ponadsektorowy wymiar klastra obejmującego swym zasięgiem zarówno horyzontalne, jak i wertykalne powiązania (Doeringer, Terkla, 1995; Rosenfeld, 1997). Niektórzy autorzy zwracają uwagę na duże znaczenie czynników społecznych i kulturowych dla sprawnego przepływu informacji w klastrze (Rosenfeld, 1997; Jacobs, DeMan, 1996).

Specyfikę struktur klastrowych określają pewne elementy determinujące budowę klastra. Należą do nich: charakter innowacji, kierunek i siła powiązania w ramach łańcuchów produkcyjnych, przepływ wiedzy i technologii, bliskość geograficzna (Jacobs, DeMan, 1996), specjalistyczna infrastruktura, wykwalifikowana siła robocza czy usługi wspierające (Rosenfeld, 1997). Większość prezentowanych w literaturze ujęć odnoszących się do definiowania klastrów (Kazimierski, 2012; Rosenfeld, 1997; Porter, 2001) nawiązuje do sieciowej współpracy oraz bliskości przestrzennej kooperujących firm. Wspólne cechy charakterystyczne i wyróżniające klaster od innych form organizacji produkcji są następujące: koncentracja przestrzenna, interakcyjność, powiązania, wspólna trajektoria rozwoju, konkurencja i kooperacja, występowanie w określonej bliskości geograficznej wzajemnie powiązanych firm, wyspecjalizowanych dostawców, podwykonawców i jednostek świadczących usługi, firm działających w sektorach pokrewnych oraz różnego rodzaju instytucji (na przykład uczelni wyższych i innych jednostek badawczych, jednostek normalizacyjnych i stowarzyszeń branżowych). Podmioty te zarówno konkurują ze sobą, jak i w pewnych obszarach współpracują. 
Mnogość definicji klastra wskazuje nie tylko na jego złożoność, ale również charakter i sposób podejścia. Dla celów syntezy można wykorzystać podejście I.R. Gordona i P. McCanna (2005) oraz S. Iammarino i P. McCanna (2006), którzy uporządkowali podejścia do definiowania klastrów, oraz podejście L. Knop (2011, s. 44). W efekcie można mówić o czterech koncepcjach definiowania klastrów, które przedstawiają się następująco:

- klastyczny model aglomeracji, gdzie rynek pracy jest swoistym odzwierciedleniem możliwości wykorzystania ekonomii skali i wskazaniem, że zewnętrzne efekty są wynikiem zarówno aktywności rynku lokalnego, jak i efektów przenikania,

- kompleks przemysłowy - odnosi się do konkretnych (szczególnych) powiązań w zakresie sprzedaży i zakupów firm, które dążą do obniżenia kosztów transakcyjnych,

- model sieci społecznej - model „klubu”, skoncentrowany na społecznych więziach i zaufaniu, które ułatwiają kooperację i innowację,

- model sieci wiedzy - model „ekspercki”, oparty na współpracy grupy naukowców, badaczy i praktyków, której celem jest tworzenie nowej wiedzy.

$\mathrm{Na}$ podstawie powyższych rozważań przyjęto, że klaster to grupa organizacji, wywodzących się z różnych środowisk (biznes, nauka, administracja, społeczeństwo obywatelskie), skoncentrowana na określonym terytorium lub problemie, skupiona wokół wspólnych idei i celów, dających podstawy do długotrwałej współpracy, opartej na rozwiniętym kapitale społecznym i generującej nową wartość dodaną. Istotą koncepcji klastra jest podejście systemowe i nielinearność procesu innowacyjnego. Klastry stanowią specyficzną formę przestrzennej organizacji sektorów przemysłu i usług uważaną za najbardziej dojrzałą formę organizacji produkcji z punktu widzenia zdolności do podtrzymywania rozwoju (Porter, 2001).

\section{Potencjał wiedzy i innowacyjności klastrów}

D la rozwoju każdego klastra bardzo istotne jest wzmacnianie potencjału wiedzy i innowacyjności. Jest to jeden z częściej występujących elementów wspierających rozwój obok takich czynników jak sposób organizacji ekonomicznej i społecznej czy profesjonalna siła robocza. Samo określenie potencjału jest powszechnie stosowane w naukach społeczno-ekonomicznych. Także autorzy zajmujący się tematyką innowacyjności przyjęli ten termin, tworząc określenia potencjału innowacyjnego i potencjału wiedzy oraz innowacyjności. Używane są one także zamiennie $\mathrm{z}$ takimi określeniami jak zdolność innowacyjna (Kasperkiewicz, 2009; Nowakowska, 2009) czy motory innowacji. Potencjał innowacyjny określany jest przez R. Guzika (2004, s. 33-36) jako zdolność do generowania dyfuzji i konsumpcji innowacji przez badane jednostki. Według autora, potencjał innowacyjny jest pochodną innowacyjności mieszkańców i firm danego regionu.
Biorąc pod uwagę powyższe rozważania, przyjęto, że potencjał wiedzy i innowacyjności klastra to zespół cech (czynników) danego klastra, a także danego układu terytorialnego sprzyjających działalności innowacyjnej, podejmowanej przez podmioty gospodarcze. Stanowi on zbiór wzajemnie powiązanych elementów zasobów (w tym głównie zasobów wiedzy), który dzięki wykonywanej pracy przekształcony zostanie w nowy stan rzeczy - dzięki możliwościom konkretnych środków i sił tworzenia nowych wartości. To także kompetencje klastra w zakresie akumulowania, wymiany, rozwijania i wykorzystywania wiedzy. Efektywność takich działań jest jedną z najistotniejszych determinant kształtowania konkurencyjności sieci.

\section{Przegląd wybranych metod i koncepcji oceny potencjału wiedzy $\mathrm{i}$ innowacyjności}

stota oraz znaczenie wiedzy i innowacyjności w procesach kształtowania konkurencyjności sieci międzyorganizacyjnych jest obecnie bezdyskusyjna. Aspekt ten, poparty licznymi badaniami, jest bardzo szeroko opisywany w literaturze przedmiotu. Celowe wydaje się zatem przytoczenie wybranych koncepcji odnoszących się do pomiaru potencjału wiedzy i innowacyjności.

Potencjał wiedzy i innowacyjności może być analizowany i oceniany za pomocą różnych metod i związanych z nimi wskaźnikami, np. metodologia OECD, metodologia Frascati, metodologia Oslo, bądź za pośrednictwem systemów statystycznych, takich jak EuroStat czy też GUS. $\mathrm{Na}$ podstawie tych metodologii tworzone są rankingi innowacyjności regionów, np.: EIS (European Innovation Scoreboard), CIS (Community Innovation Surveys) czy też SII (Summary Innovation Index). Wskazane metodologie niewątpliwie mają wiele zalet, gdyż zapewniają stały, bezpłatny dopływ obiektywnych, zweryfikowanych statystycznie danych, świadczących o intensywności współpracy w zakresie innowacyjnej działalności i, często już na poziomie regionów, dają możliwości porównawcze. Pamiętać jednak należy, że współcześnie zachodzi wiele zmian warunkujących procesy innowacyjne, takie jak: intensyfikacja wymiany wiedzy, funkcjonowanie modelu otwartej innowacji, łatwy dostęp do informacji patentowej oraz wiedzy naukowej. Te szybkie zmiany powodują, że dziś statystyka publiczna nie daje możliwości pełnego obrazowania tych procesów. W kontekście współczesnych uwarunkowań jednym $\mathrm{z}$ istotnych kierunków rozwoju badań i pomiarów dotyczących nauki, techniki i innowacji jest metoda analizy sieci (Social/Organizational Network Analysis - SNA/ONA)

W wielu publikacjach naukowych proponowane są również oceny potencjału innowacyjnego regionów wykorzystujące metody taksonomiczne bazujące na konstrukcji miar syntetycznych, np.: metodę Perkala czy też taksonomiczną miarę rozwoju Z. Hellwiga. Te metody wykorzystane mogą być także do analizy potencjału wiedzy i innowacyjności $w$ sieciach międzyorganizacyjnych. 
Przegląd literatury przedmiotu wskazuje na duże zainteresowanie problematyką innowacyjności klastrów zarówno przez autorów polskich (Olesiński i in., 2016; Moszkowicz, Bembenek, 2017), jak i zagranicznych (Powell, Grodal, 2006; Schiuma, Lerro, 2010; Zhao i in., 2010). Zdecydowanie brakuje jednak opracowań w zakresie sposobów pomiaru potencjału innowacyjności klastrów. Wśród propozycji metod i mierników innowacyjności zdecydowanie przeważają te, które odnoszą się do badania przedsiębiorstw (Anthony, 2010; Nawrocki, 2015; Szymura-Tyc, 2015). Ocena innowacyjności klastrów determinowana jest głównie przez występowanie relacji sieciowych, dlatego warto w tym miejscu przytoczyć badania Ph. Aydalota, który jako jeden z pierwszych badaczy poszukiwał warunków zewnętrznych niezbędnych do tworzenia nowych firm i decydujących o ich zdolnościach innowacyjnych. Jego zdaniem, innowacje są silnie powiązane $\mathrm{z}$ lokalnym środowiskiem innowacyjnym (innovative milieu), tym samym innowacje nie są produktem pojedynczych jednostek, ale rezultatem wspólnego działania.

Dyskusja nad metodologiami pomiaru potencjału wiedzy i innowacyjności, poparta licznymi publikacjami (Bojewska, 2013, s. 153-201; Sopińska, 2013; McCosh i in., 1998, s. 175-193), ma zarówno wymiar akademicki, jak i praktyczny, gdyż właśnie praktyka gospodarcza jest niezwykle zainteresowana skutecznymi narzędziami pomiaru i oceny zdolności innowacyjnej oraz skuteczności procesów innowacyjnych. W prezentowanych koncepcjach wskazuje się na różnorodne miary oceny potencjału wiedzy i innowacyjności (Nawrocki, 2015). Analiza literatury wskazuje, że często spotykane kryteria podziału mierników oceny innowacyjności to: potencjał innowacyjny, proces innowacyjny oraz efekty procesów innowacyjnych, zaś Boston Consulting Group sugeruje, by $w$ celu oceny działalności innowacyjnej stosować pewną zrównoważoną kompozycję mierników w trzech kategoriach: nakładów, procesów i wyników. Wielu badaczy kładzie nacisk na wyniki związane $z$ innowacyjnością, lecz istnieje także kilka koncepcji (Adams i in. 2016), w których propaguje się podejście holistyczne i aspekt pomiaru procesu innowacyjnego, a nie samych nakładów i wyników (Nawrocki, 2015).

Duże organizacje wykształciły efektywne metody i narzędzia służące praktycznej ocenie własnych zdolności innowacyjnych. Przykładem takich narzędzi mogą być audyty innowacyjności, benchmarking innowacyjności czy też mierniki zawarte w zrównoważonej karcie wyników BCS.

W odniesieniu do klastrów w literaturze opisywane są metody pozwalające oceniać funkcjonowanie, innowacyjność i konkurencyjność klastrów, a także wyniki badań w zakresie oceny innowacyjności klastrów (Olesiński i in., 2016; Moszkowicz, Bembenek, 2017; Plawgo, 2014; Zhao i in., 2010). Badania empiryczne struktur klastrowych napotykają jednak na problem znacznego zróżnicowania metodologii badawczych, co prowadzi do trudności przy porównywaniu funkcjonowania i innowacyjności różnych klastrów. W opublikowanych do tej pory badaniach zastosowano różne podejścia dosto- sowane zarówno do poziomu agregacji badania - lokalnego, regionalnego, sektorowego czy narodowego, jak i do dostępnych danych statystycznych i jakościowych. Badania klastrów często przeprowadzane są w oparciu o analizę jakościową opartą na wywiadach, studiach przypadku. Głównymi problemami przy stosowaniu tej metody są subiektywizm oceny danych o charakterze jakościowym oraz trudności z porównywalnością otrzymanych wyników.

W niektórych opracowaniach (Skawińska, Zalewski, 2009; Kowalski, 2013) prezentowane są wyniki polskich badań nad funkcjonowaniem klastrów, w tym również dotyczące oceny ich potencjału innowacyjnego. Analiza tych badań pozwala na stwierdzenie, że brakuje propozycji, w których prezentowane byłyby kryteria oceny i zoperacjonizowany sposób pomiaru. Badania w zakresie oceny potencjału innowacyjności klastrów prowadzi także Polska Agencja Rozwoju Przedsiębiorczości (PARP) (trzy edycje badań bechmarkingowych w okresie 2010-2015).

Warto także przywołać ciekawe badania w zakresie wpływu innowacyjności i wiedzy na rozwój sieci, które przeprowadzili A.P. de Man i G. Duysters (2005), analizując zawartości publikacji dokumentujących wyniki badań empirycznych prowadzonych na dużą skalę, pozwalającą na generalizację wniosków (tj. wykraczającą poza pojedyncze przypadki). Wyniki badań pokazały, iż w większości przypadków (73\% publikacji) wystąpił pozytywny związek pomiędzy formowaniem sieci a innowacyjnością. Nieliczne przypadki (17\%) miały charakter neutralny, a w pojedynczych przypadkach (10\%) wykazano negatywny wpływ współpracy sieciowej na innowacyjność (de Man, Duyers, 2005, s. 1380). W literaturze opisywane są też nieliczne przypadki wykorzystywania współpracy sieciowej do obniżania innowacyjności współpracujących firm. Przykładowo, badania ujawniły, że większość stosowanych przez firmę Microsoft form wsparcia dla partnerów prowadziła bezpośrednio do ograniczenia przez partnerów nowych produktów, które mogły stanowić konkurencję dla rozwiązań Microsoftu. Wskazuje to na fakt, że chociaż udział w sieciach partnerskich powinien stymulować transfer technologii, wzajemne uczenie się, dzielenie się wiedzą i współpracę $\mathrm{B}+\mathrm{R}$, to mimo wszystko $\mathrm{w}$ wielu przypadkach firmy mniej chętnie dzielą się specjalistyczną wiedzą z innymi członkami sieci, gdy członkami sieci są podmioty bezpośrednio konkurujące o tych samych odbiorców końcowych (Gomes-Casseres, 1996, s. 78-83).

Analiza opisanych podejść wskazuje na duże zróżnicowania, wieloaspektowość i złożoność zjawisk kształtujących potencjał wiedzy i innowacyjności. Problem ten szczególnego znaczenia nabiera w przypadku sieci międzyorganizacyjnych i zmusza do poszukiwania optymalnych metod analizy i oceny tego obszaru. Można pokusić się o stwierdzenie, że mimo coraz liczniej pojawiających się opracowań teoretycznych i empirycznych na temat pomiaru potencjału wiedzy i innowacyjności wciąż można mówić o niedostatku badań w tym zakresie, a zwłaszcza braku kompleksowych propozycji metodycznych. 
Prezentowane $\mathrm{w}$ literaturze badania są obarczone pewnymi mankamentami: koncepcja oceny potencjału wiedzy i innowacyjności jest słabo określona i niedostatecznie zoperacjonalizowana, w badaniach wykorzystuje się niewiele miar, niejasne są możliwości stosowania poszczególnych wskaźników w zależności od charakterystyki działania sieci. Ponadto wątpliwości również może budzić dobór kryteriów oceny, które koncentrują się najczęściej na określeniu poziomu innowacyjności, pomijając aspekty związane $\mathrm{z}$ zarządzaniem wiedzą i uczeniem się organizacji. Problematyka ta dotyczy w szczególności klastrów. O ile sam problem innowacyjności klastrów jest analizowany w literaturze dość często, o tyle brakuje badań w zakresie sposobów jego pomiaru. Analiza literatury pozwala sformułować tezę, iż istnieje w tym zakresie duża luka poznawcza i badawcza, brakuje zwłaszcza propozycji metodologicznych.

W dalszej części artykułu zaprezentowano autorską metodę oceny potencjału wiedzy i innowacyjności klastrów wraz ze wskazaniem kryteriów i wzorców oceny.

\section{Metoda oceny potencjału wiedzy i innowacji klastrów}

K oncepcja badawcza oparta jest na wieloaspektowym ujęciu potencjału wiedzy i innowacyjności klastrów. Prezentowana metoda jest ukierunkowana na wielokryterialną ocenę potencjału wiedzy i innowacyjności klastrów, przeprowadzoną w wymiarze zarządzania wiedzą i organizacyjnego uczenia się oraz w wymiarze innowacyjności. Wykorzystano tu wielokryterialną ocenę agregatową uwzględniającą ustalone wzorce i kryteria oceny (Barczak, 2016). Charakterystycznym wyróżnikiem oceny agregatowej jest zasada scalenia pojedynczych kryteriów dla potrzeb uzyskania odpowiedzi na pytanie o ogólną wartość badanego obiektu. W takim rozumieniu ocena agregatowa może służyć jako instrument wspomagający przeprowadzenie oceny potencjału wiedzy i innowacyjności sieci międzyorganizacyjnych. Podejście to ma zdecydowaną przewagę merytoryczną nad podejściami jednokryterialnymi, stąd postulat wiązania poszczególnych kryteriów oceny w układ komplementarny. Jest to problem rodzajowego i ilościowego doboru kryteriów oceny oraz ich agregacji (Stabryła, 2016).

Postępowanie badawcze w proponowanej metodzie obejmuje następujące etapy:

1. Ustalenie zakresu badania.

2. Sformułowanie kryteriów oceny.

3. Określenie wag kryteriów oceny.

4. Ustalenie wartości wzorcowych dla kryteriów oceny.

5. Przeprowadzenie oceny sprawdzającej.

6. Kategoryzacja badanych klastrów.

7. Sformułowanie ustaleń diagnostycznych.

Szczególnie istotne $\mathrm{z}$ punktu widzenia wielokryterialnej oceny agregatowej jest ustalenie kryteriów i wzorców oceny. Dla celów ich opracowania przeprowadzono badania empiryczne w 63 klastrach i inicjatywach klastrowych działających w różnych branżach za pomocą kwestionariusza ankiety. Kwestionariusz ankiety został skierowany do koordynatorów klastrów i inicjatyw klastrowych zidentyfikowanych na podstawie bazy klastrów zawartej w Portalu innowacji - klastry (Portal innowacji - klastry, 2013). W strukturze badanych klastrów większość (ponad 59\%) stanowiły klastry o zasięgu regionalnym, 18,5\% miało zasięg krajowy i międzynarodowy, a tylko 3,7\% badanych sieci to klastry o zasięgu globalnym. Najwięcej badanych klastrów funkcjonowało w branży informatycznej i telekomunikacyjnej. Badania opinii koordynatorów klastrów przeprowadzono na podstawie metod CAWI (Computer Assisted Web Interview) i CATI (Computer Assisted Telephone Interview).

W pierwszym etapie postępowania określono zakres badania, a następnie przeprowadzono dobór mierników o charakterze diagnostycznym, które w tym przypadku służą do orzekania, jaki jest stan faktyczny. Kryteria oceny są cechami lub parametrami o charakterze aksjologicznym (wartościującym). Dobór rodzajowy i ilościowy kryteriów oceny został dokonany w dwóch etapach: (1) przeprowadzenie pierwszej selekcji kryteriów oceny (podział kryteriów na relewantne i mało istotne lub nieistotne), (2) określenie struktury kryteriów oceny: podział relewantnych kryteriów oceny na grupy rodzajowe (kryteria dotyczące oceny zarządzania wiedzą i organizacyjnego uczenia się i kryteria dotyczące oceny innowacyjności) oraz podział kryteriów na syntetyczne i cząstkowe.

Do określenia kryteriów oceny wykorzystano opisywane w literaturze podejścia oraz zintegrowane modele, które mogą być użyteczne w ocenie potencjału wiedzy i innowacyjności sieci międzyorganizacyjnych (European Innovation Scoreboard, Community Innovation Surveys, Summary Innovation Index). Punktem wyjścia przy formułowaniu kryteriów oceny było przyjęcie założenia, że potencjał wiedzy i innowacyjności jest pojęciem złożonym (wieloaspektowym), co wymaga rozpatrywania różnych aspektów, wykorzystując zarówno ilościowe, jak i jakościowe kryteria. Struktura proponowanych kryteriów oceny jest zatem różnorodna, ale przy ich formułowaniu kierowano się zasadą komplementarności poszczególnych kryteriów.

W dalszej kolejności należy ustalić rangi kryteriów oceny. Rangi przyporządkowane są poszczególnym kryteriom oceny na podstawie skali trzypunktowej: 3 punkty - kryteria dominujące, 2 punkty - kryteria zasadnicze, 1 punkt - kryteria przydatne.

W celu przeprowadzenia kwalifikacji kryteriów oceny wykorzystano metodę opinii ekspertów. Osądy ekspertów stanowią w tym przypadku wypadkową własnych opinii ekspertów. Grupę ekspertów stanowili koordynatorzy badanych klastrów (10) oraz eksperci zewnętrzni, w tym również pracownicy naukowi (5).

Dla wybranych kryteriów oceny przyjęto wartości wzorcowe, które rozumiane są jako zestawienie kryteriów oceny, tworzących pewien agregat, który stanowi wielokryterialny układ wartościujący. Określenie wartości poszczególnych kryteriów nastąpiło poprzez 
Tabela 1. Kryteria i wzorce oceny potencjału wiedzy i innowacyjności sieci międzyorganizacyjnych

\begin{tabular}{|c|c|c|c|}
\hline Wymiary & $\begin{array}{c}\text { Kryteria } \\
\text { syntetyczne }\end{array}$ & Kryteria cząstkowe & Wzorce \\
\hline \multirow[t]{4}{*}{$\begin{array}{l}\text { Zarządzanie } \\
\text { wiedzą } \\
\text { i organizacyjnym } \\
\text { uczeniem się }\end{array}$} & $\begin{array}{l}\text { K1. Dzielenie się } \\
\text { wiedzą }\end{array}$ & $\begin{array}{l}\text { 1. dzielenie się wiedzą } \\
\text { z kooperantami } \\
\text { 2. dzielenie się wiedzą wewnątrz } \\
\text { sieci } \\
\text { 3. bariery w dzieleniu się wiedzą }\end{array}$ & $\begin{array}{l}\text { 1. większość podmiotów sieci tworzy wspólne bazy } \\
\text { z kooperantami } \\
\text { 2. występuje znaczny stopień wykorzystania nowoczesnych } \\
\text { technologii dla usprawniania kontaktów z kooperantami } \\
\text { 3. podmioty sieci w znacznym stopniu pozyskują od } \\
\text { kooperantów informacje niezbędne do usprawniania } \\
\text { swojej działalności } \\
\text { 4. podmioty dobrze oceniają wzajemną wymianę informacji } \\
\text { 5. istnieją techniczne i organizacyjne rozwiązania systemów } \\
\text { gromadzenia wiedzy } \\
\text { 6. wiedza jest gromadzona i odpowiednio rozpowszechniana } \\
\text { 7. występuje dobra komunikacja } \\
\text { 8. istnieje rozbudowana infrastruktura informatyczna } \\
\text { 9. występuje odpowiedni styl zarządzania } \\
\text { 10. nie występuje rywalizacja między pracownikami }\end{array}$ \\
\hline & $\begin{array}{l}\text { K2. Grupowe } \\
\text { rozwiązywanie } \\
\text { problemów }\end{array}$ & $\begin{array}{l}\text { 1. wzajemne kontakty } \\
\text { i korzystanie z pomocy } \\
\text { pracowników kompetentnych } \\
\text { w danej dziedzinie } \\
\text { 2. bariery utrudniające } \\
\text { wykorzystanie i wymianę } \\
\text { wiedzy między pracownikami } \\
\text { 3. udział w pracach projektowych } \\
\text { i kołach jakości } \\
\text { 4. premiowanie efektów prac } \\
\text { grupowych }\end{array}$ & $\begin{array}{l}\text { 1. w każdej chwili musi być dostępna informacja } \\
\text { o pracownikach dysponujących określonymi zasobami } \\
\text { wiedzy } \\
\text { 2. istnieje możliwość wzajemnego kontaktu i korzystania } \\
\text { z pomocy pracowników kompetentnych w danej dziedzinie } \\
\text { 3. nie ma barier utrudniających wymianę wiedzy między } \\
\text { pracownikami } \\
\text { 4. nie ma rywalizacji, preferowane są raczej efekty pracy } \\
\text { grupowej niż indywidualnej } \\
\text { 5. pracowników zachęca się do zespołowego rozwiązywania } \\
\text { problemów oraz dzielenia się pomysłami } \\
\text { 6. pracownicy mogą brać udział w pracach projektowych } \\
\text { 7. efekty prac grupowych są premiowane }\end{array}$ \\
\hline & $\begin{array}{l}\text { K3. } \\
\text { Wykorzystanie } \\
\text { systemów } \\
\text { informatycznych }\end{array}$ & $\begin{array}{l}\text { 1. stopień wykorzystania } \\
\text { systemów informatycznych } \\
\text { 2. stopień realizacji funkcji } \\
\text { systemu w stosunku do potrzeb } \\
\text { informacyjnych użytkownika } \\
\text { 3. zastosowanie multimediów } \\
\text { sieciowych } \\
\text { 4. wykorzystanie narzędzi } \\
\text { wspomagających zarządzanie } \\
\text { wiedzą }\end{array}$ & $\begin{array}{l}\text { 1. wykorzystywane są następujące systemy: transakcyjne } \\
\text { (ST), z bazą danych, wspomagania decyzji (SWD), } \\
\text { informowania kierownictwa (SIK), eksperckie (SE), } \\
\text { inteligentnego wspomagania decyzji (SIWD), wczesnego } \\
\text { ostrzegania (SWO), symulacyjne (DSS), sztuczna } \\
\text { inteligencja } \\
\text { 2. wzorcowym poziomem wskaźnika jest wartość 100\%, } \\
\text { oznaczająca, iż system posiada funkcje, które w pełni } \\
\text { zaspokajają potrzeby użytkownika } \\
\text { 3. sieć wykorzystuje aplikacje multimedialne związane } \\
\text { z transmisją danych za pośrednictwem sieci złożonych } \\
\text { 4. sieć wykorzystuje większość z wymienionych narzędzi: } \\
\text { bazy danych o klientach, produktach, technologiach, } \\
\text { rynku, konkurentach, systemy obiegu dokumentów, } \\
\text { systemy wideokonferencji, Internet, portale WWW, poczta } \\
\text { elektroniczna }\end{array}$ \\
\hline & $\begin{array}{l}\text { K4. Komunikacja } \\
\text { wewnętrzna }\end{array}$ & $\begin{array}{l}\text { 1. wykorzystanie technologii } \\
\text { informatycznych w procesach } \\
\text { komunikowania się } \\
\text { 2. znajomość źródeł informacji } \\
\text { 3. bariery utrudniające wymianę } \\
\text { informacji } \\
\text { 4. skuteczność komunikowania się } \\
\text { 5. nieformalne kanały informacji } \\
\text { 6. wykorzystanie systemów } \\
\text { informatycznych do } \\
\text { rozpowszechniania wiedzy }\end{array}$ & $\begin{array}{l}\text { 1. wykorzystywane technologie informatyczne w wysokim } \\
\text { stopniu usprawniają system komunikacji wewnętrznej } \\
\text { 2. pracownicy wiedzą, gdzie szukać określonych źródeł } \\
\text { informacji } \\
\text { 3. nie ma barier utrudniających wymianę informacji } \\
\text { 4. istnieją umiejętności na poziomie sieci, które może } \\
\text { wykorzystać zarówno nadawca, jak i odbiorca } \\
\text { 5. nieformalny obieg informacji jest kontrolowany poprzez } \\
\text { utrzymywanie otwartych kanałów komunikacji i szybkie } \\
\text { reakcje na nieprawdziwe informacje } \\
\text { 6. do rozpowszechniania wiedzy wykorzystuje się systemy } \\
\text { informatyczne ST, z bazą danych, SWD, SIK, SE, SIWD, } \\
\text { DSS oraz multimedia }\end{array}$ \\
\hline
\end{tabular}




\begin{tabular}{|c|c|c|c|}
\hline Wymiary & $\begin{array}{c}\text { Kryteria } \\
\text { syntetyczne }\end{array}$ & Kryteria cząstkowe & Wzorce \\
\hline \multirow[t]{3}{*}{ Innowacyjność } & $\begin{array}{l}\text { K5. Działalność } \\
\text { inwestycyjna } \\
\text { i nakłady }\end{array}$ & $\begin{array}{l}\text { 1. wskaźnik inwestycji (nakłady } \\
\text { inwestycyjne jako procent } \\
\text { przychodów) } \\
\text { 2. nakłady na nowe produkty do } \\
\text { nakładów ogółem } \\
\text { 3. nakłady na B+R do przychodów }\end{array}$ & $\begin{array}{l}\text { 1. wskaźnik inwestycji (nakłady inwestycyjne jako procent } \\
\text { przychodów) przyjmuje poziom wyższy od średniej dla } \\
\text { danej branży } \\
\text { 2. wskaźnik nakładów na nowe produkty do nakładów } \\
\text { ogółem kształtuje się na poziomie wyższym od średniej dla } \\
\text { danej branży } \\
\text { 3. wskaźnik nakładów na B+R do przychodów kształtuje się } \\
\text { na poziomie wyższym od średniej dla danej branży }\end{array}$ \\
\hline & $\begin{array}{l}\text { K6. Prace } \\
\text { badawczo- } \\
\text {-rozwojowe }\end{array}$ & $\begin{array}{l}\text { 1. dokumentacja } \mathrm{B}+\mathrm{R} \\
\text { 2. liczba opanowanych technologii } \\
\text { wytwórczych i rynków } \\
\text { 3. zmiany w zakresie strategii } \\
\text { działania } \\
\text { 4. innowacje organizacyjne } \\
\text { i techniczne } \\
\text { 5. badania rynkowe w celu } \\
\text { wprowadzenia nowego } \\
\text { produktu } \\
\text { 6. wprowadzenie lub } \\
\text { udoskonalenie produktu lub } \\
\text { procesu } \\
\text { 7. prace badawcze o charakterze } \\
\text { eksperymentalnym lub } \\
\text { stosowanym } \\
\text { 8. zaawansowane techniki } \\
\text { zarządzania }\end{array}$ & $\begin{array}{l}\text { Sieć: } \\
\text { 1. posiada patent(y) na opracowany przez siebie wynalazek, } \\
\text { zrealizowała projekt(y) racjonalizatorskie, zarejestrowała } \\
\text { znak(i) towarowy } \\
\text { 2. opanowała przynajmniej jedną technologię wytwórczą lub } \\
\text { rynek } \\
\text { 3. wdrożyła nową lub istotnie zmienioną strategię działania } \\
\text { 4. wprowadziła przynajmniej jedną innowację organizacyjną } \\
\text { lub techniczną } \\
\text { 5. prowadzi badania rynkowe w celu wdrożenia nowego } \\
\text { produktu lub usługi } \\
\text { 6. z powodzeniem wprowadziła lub znacząco udoskonaliła } \\
\text { produkt lub procesy } \\
\text { 7. prowadzi prace B+R o charakterze eksperymentalnym lub } \\
\text { stosowanym } \\
\text { 8. wdrożyła zaawansowane techniki zarządzania (TQM, BSC) }\end{array}$ \\
\hline & $\begin{array}{l}\text { K7. Współpraca } \\
\text { w zakresie } \\
\text { rozwoju }\end{array}$ & $\begin{array}{l}\text { 1. współpraca } z \text { instytucjami } \\
\text { naukowo-badawczymi } \\
\text { 2. współpraca } z \text { klientami } \\
\text { i dostawcami } \\
\text { 3. seminaria i konferencje } \\
\text { naukowe }\end{array}$ & $\begin{array}{l}\text { 1. przedsiębiorstwa należące do sieci współpracują } \\
\text { z uczelniami, placówkami naukowymi, centrami transferu } \\
\text { technologii, jednostkami badawczo-rozwojowymi } \\
\text { 2. podmioty sieci podejmują współpracę z klientami } \\
\text { i dostawcami w celu zdobycia wiedzy służącej } \\
\text { wprowadzaniu nowego rozwiązania } \\
\text { 3. podmioty sieci uczestniczą w seminariach i konferencjach } \\
\text { naukowych }\end{array}$ \\
\hline
\end{tabular}

Źródto: opracowanie własne

przypisanie im odpowiednio dobranego zakresu pytań w wykorzystanej do badań ankiecie. Zestawienie kryteriów i wzorców oceny w poszczególnych wymiarach przedstawiono $\mathrm{w}$ tabeli 1 . Zaprezentowany zestaw kryteriów zawiera zarówno ilościowe, jak i jakościowe kryteria. Wykaz ten powstał na podstawie analizy źródeł literaturowych i przytoczonych wcześniej metod oceny innowacyjności klastrów, jak również na podstawie badań empirycznych - ankiety i wywiadów z koordynatorami klastrów. Może on być bardziej rozbudowany i uszczegółowiony, ale można go też zredukować. Dobór kryteriów oceny jest związany bowiem $z$ ustalonym zakresem badań.

Istotą proponowanej metody jest porównanie kryteriów oceny do wartości wzorcowych, co przeprowadzone jest w etapie punktowej oceny sprawdzającej, która ma wskazać, w jakim stopniu dany podmiot respektuje założone wymagania (wyrażone przez wzorce oceny osiągnięć). Interpretacja wyników i ich tendencji jest sprawą zasadniczą dla postawienia właściwej oceny sprawdzającej, zwłaszcza w sytuacji stosowania modelu wielokryterialnego (Stabryła, 2011). Dla przeprowadzenia punktowej oceny sprawdzającej przyjęto znormalizowaną ocenę pięciopunktową.

W tabeli 2 przedstawiono operacjonalizację kryteriów oceny i sposób ich przeliczania na wartości punktowe.

W kolejnym etapie postępowania dla każdej badanej sieci należy ustalić wartość indeksu potencjału wiedzy i innowacyjności (IWI). Indeks IWI stanowi iloczyn rangi j-tego kryterium oceny i punktowej oceny sprawdzającej odniesionej do i-tej sieci. Ranga j-tego kryterium ustalana jest poprzez wykorzystanie metody badania opinii ekspertów (w prowadzonych badaniach byli to koordynatorzy klastrów i eksperci zewnętrzni). Ocenę ekspertów przeprowadzono na podstawie skali trzypunktowej (1-3).

$\mathrm{W}$ etapie rangowania $\mathrm{w}$ pierwszej kolejności na podstawie opracowanej tabeli przeliczników należy ustalić wartość punktową indeksu IWI. W przeprowadzonych 
Tabela 2. Tabela przeliczników dla punktowej oceny sprawdzającej

\begin{tabular}{|c|c|c|c|c|c|}
\hline \multirow{2}{*}{$\begin{array}{l}\text { Kryteria } \\
\text { oceny }\end{array}$} & \multicolumn{5}{|c|}{ Punktacja } \\
\hline & $\begin{array}{c}\text { Stan niedostateczny } \\
0\end{array}$ & $\begin{array}{c}\text { Stan dopuszczalny } \\
1\end{array}$ & $\begin{array}{c}\text { Stan średni } \\
2\end{array}$ & $\begin{array}{c}\text { Stan dobry } \\
3\end{array}$ & $\begin{array}{c}\text { Stan wyróżniający } \\
4\end{array}$ \\
\hline K1 & $\begin{array}{l}\text { - podmioty klastra nie } \\
\text { tworzą wspólnych } \\
\text { baz danych z koope- } \\
\text { rantami i klientami } \\
\text { - brak barier dzielenia } \\
\text { się wiedzą }\end{array}$ & $\begin{array}{l}\text { - podmioty klastra } \\
\text { w niewielkim } \\
\text { stopniu tworzą } \\
\text { wspólne bazy danych } \\
\text { z kooperantami } \\
\text { i klientami } \\
\text { - bariery dzielenia się } \\
\text { wiedzą występu- } \\
\text { ją w niewielkim } \\
\text { stopniu }\end{array}$ & $\begin{array}{l}\text { - podmioty klastra } \\
\text { w średnim stopniu } \\
\text { tworzą wspólne bazy } \\
\text { danych z kooperan- } \\
\text { tami i klientami } \\
\text { - bariery dzielenia się } \\
\text { wiedzą występują } \\
\text { w średnim stopniu }\end{array}$ & $\begin{array}{l}\text { - podmioty klastra } \\
\text { w dużym stopniu } \\
\text { tworzą wspólne bazy } \\
\text { danych z kooperan- } \\
\text { tami i klientami } \\
\text { - bariery dzielenia się } \\
\text { wiedzą występują } \\
\text { w dużym stopniu }\end{array}$ & $\begin{array}{l}\text { - podmioty klastra } \\
\text { w bardzo dużym } \\
\text { stopniu tworzą } \\
\text { wspólne bazy danych } \\
\text { z kooperantami } \\
\text { i klientami } \\
\text { - bariery dzielenia się } \\
\text { wiedzą występują } \\
\text { w bardzo dużym } \\
\text { stopniu }\end{array}$ \\
\hline $\mathrm{K} 2$ & $\begin{array}{l}\text { - dla żadnego z kry- } \\
\text { teriów cząstkowych } \\
\text { nie są spełnione } \\
\text { warunki określone } \\
\text { przez stan wzorcowy }\end{array}$ & $\begin{array}{l}\text { - dla przynajmniej } \\
2 \text { z } 4 \text { kryteriów cząst- } \\
\text { kowych spełnione } \\
\text { są warunki określone } \\
\text { przez stan wzorcowy }\end{array}$ & $\begin{array}{l}\text { - dla } 3 \text { z } 4 \text { kryte- } \\
\text { riów cząstkowych } \\
\text { spełnione są warunki } \\
\text { określone przez stan } \\
\text { wzorcowy }\end{array}$ & $\begin{array}{l}\text { - dla } 4 \text { z } 4 \text { kryte- } \\
\text { riów cząstkowych } \\
\text { spełnione są warunki } \\
\text { określone przez stan } \\
\text { wzorcowy }\end{array}$ & $\begin{array}{l}\text { - dla każdego z kry- } \\
\text { teriów cząstkowych } \\
\text { spełnione są warunki } \\
\text { określone przez stan } \\
\text { wzorcowy }\end{array}$ \\
\hline K3 & $\begin{array}{l}\text { - nie wykorzystuje się } \\
\text { żadnych systemów } \\
\text { informatycznych } \\
\text { - stopień realizacji } \\
\text { funkcji systemu } \\
\text { w stosunku do } \\
\text { potrzeb informacyj- } \\
\text { nych użytkownika } \\
\text { na poziomie poniżej } \\
60 \% \\
\text { - wykorzystanie } \\
\text { narzędzi zarządzania } \\
\text { wiedzą i multime- } \\
\text { diów na poziomie } \\
\text { poniżej } 60 \%\end{array}$ & $\begin{array}{l}\text { - wykorzystywane } \\
\text { są systemy z bazą } \\
\text { danych } \\
\text { - stopień realizacji } \\
\text { funkcji systemu } \\
\text { w stosunku do } \\
\text { potrzeb informacyj- } \\
\text { nych użytkownika na } \\
\text { poziomie } 60-74 \% \\
\text { - wykorzystanie } \\
\text { narzędzi zarządzania } \\
\text { wiedzą i multime- } \\
\text { diów na poziomie } \\
60-74 \%\end{array}$ & $\begin{array}{l}\text { - wykorzystywane } \\
\text { są systemy: ST, } \\
\text { z bazą danych } \\
\text { - stopień realizacji } \\
\text { funkcji systemu } \\
\text { w stosunku do } \\
\text { potrzeb informacyj- } \\
\text { nych użytkownika na } \\
\text { poziomie } 75-84 \% \\
\text { wykorzystanie } \\
\text { narzędzi zarządzania } \\
\text { wiedzą i multime- } \\
\text { diów na poziomie } \\
\text { 75-84\% }\end{array}$ & $\begin{array}{l}\text { - wykorzystywane } \\
\text { są systemy: ST, } \\
\text { z bazą danych, SWD, } \\
\text { SIK } \\
\text { - stopień realizacji } \\
\text { funkcji systemu } \\
\text { w stosunku do } \\
\text { potrzeb informacyj- } \\
\text { nych użytkownika na } \\
\text { poziomie } 85-99 \% \\
\text { - wykorzystanie } \\
\text { narzędzi zarządzania } \\
\text { wiedzą i multime- } \\
\text { diów na poziomie } \\
\text { 85-99\% }\end{array}$ & $\begin{array}{l}\text { - wykorzystywane } \\
\text { są systemy: ST, } \\
\text { z bazą danych, SWD, } \\
\text { SIK, SE, SIWD, } \\
\text { SWO, DSS } \\
\text { - stopień realizacji } \\
\text { funkcji systemu } \\
\text { w stosunku do } \\
\text { potrzeb informacyj- } \\
\text { nych użytkownika na } \\
\text { poziomie } 100 \% \\
\text { - wykorzystanie } \\
\text { narzędzi zarządzania } \\
\text { wiedzą i multime- } \\
\text { diów na poziomie } \\
100 \%\end{array}$ \\
\hline K4 & $\begin{array}{l}\text { - dla żadnego z kry- } \\
\text { teriów cząstkowych } \\
\text { nie są spełnione } \\
\text { warunki określone } \\
\text { przez stan wzorcowy }\end{array}$ & $\begin{array}{l}\text { - dla przynajmniej } \\
3 \text { z } 6 \text { kryteriów cząst- } \\
\text { kowych spełnione } \\
\text { są warunki określone } \\
\text { przez stan wzorcowy }\end{array}$ & $\begin{array}{l}\text { - dla } 4 \text { z } 6 \text { kryte- } \\
\text { riów cząstkowych } \\
\text { spełnione są warunki } \\
\text { określone przez stan } \\
\text { wzorcowy }\end{array}$ & $\begin{array}{l}\text { - dla } 5 \text { z } 6 \text { kryte- } \\
\text { riów cząstkowych } \\
\text { spełnione są warunki } \\
\text { określone przez stan } \\
\text { wzorcowy }\end{array}$ & $\begin{array}{l}\text { - dla każdego z kry- } \\
\text { teriów cząstkowych } \\
\text { spełnione są warunki } \\
\text { określone przez stan } \\
\text { wzorcowy }\end{array}$ \\
\hline K5 & $\begin{array}{l}\text { poziom wskaźników } \\
\text { zdecydowanie niższy } \\
\text { w porównaniu do } \\
\text { firm tej samej branży }\end{array}$ & $\begin{array}{l}\text { poziom wskaźników } \\
\text { nieznacznie niższy } \\
\text { w porównaniu do } \\
\text { firm tej samej branży }\end{array}$ & $\begin{array}{l}\text { wskaźniki osiągają } \\
\text { poziom średni dla } \\
\text { danej branży }\end{array}$ & $\begin{array}{l}\text { poziom wskaźników } \\
\text { wyższy w porówna- } \\
\text { niu do firm tej samej } \\
\text { branży }\end{array}$ & $\begin{array}{l}\text { poziom wskaźni- } \\
\text { ków zdecydowanie } \\
\text { wyższy w porówna- } \\
\text { niu do firm tej samej } \\
\text { branży }\end{array}$ \\
\hline K6 & $\begin{array}{l}\text { - dla żadnego z kry- } \\
\text { teriów cząstkowych } \\
\text { nie są spełnione } \\
\text { warunki określone } \\
\text { przez stan wzorcowy }\end{array}$ & $\begin{array}{l}\text { - dla przynajmniej } \\
5 \text { z } 8 \text { kryteriów cząst- } \\
\text { kowych spełnione } \\
\text { są warunki określone } \\
\text { przez stan wzorcowy }\end{array}$ & $\begin{array}{l}\text { - dla } 6 \text { z } 8 \text { kryte- } \\
\text { riów cząstkowych } \\
\text { spełnione są warunki } \\
\text { określone przez stan } \\
\text { wzorcowy }\end{array}$ & $\begin{array}{l}\text { - dla } 6 \text { z } 8 \text { kryte- } \\
\text { riów cząstkowych } \\
\text { spełnione są warunki } \\
\text { określone przez stan } \\
\text { wzorcowy }\end{array}$ & $\begin{array}{l}\text { - dla każdego z kry- } \\
\text { teriów cząstkowych } \\
\text { spełnione są warunki } \\
\text { określone przez stan } \\
\text { wzorcowy }\end{array}$ \\
\hline K7 & $\begin{array}{l}\text { - brak współpracy } \\
\text { z instytucjami na- } \\
\text { ukowo-badawczymi, } \\
\text { klientami i dostaw- } \\
\text { cami } \\
\text { - podmioty sieci nie } \\
\text { uczestniczą w semi- } \\
\text { nariach i konferen- } \\
\text { cjach naukowych }\end{array}$ & $\begin{array}{l}\text { niewielki stopień } \\
\text { współpracy z insty- } \\
\text { tucjami naukowo- } \\
\text {-badawczymi, klien- } \\
\text { tami i dostawcami } \\
\text { - podmioty sieci } \\
\text { w niewielkim } \\
\text { stopniu uczestni- } \\
\text { czą w seminariach } \\
\text { i konferencjach } \\
\text { naukowych }\end{array}$ & $\begin{array}{l}\text { - średni stopień } \\
\text { współpracy z insty- } \\
\text { tucjami naukowo- } \\
\text {-badawczymi, klien- } \\
\text { tami i dostawcami } \\
\text { - podmioty sieci } \\
\text { w średnim stopniu } \\
\text { uczestniczą w semi- } \\
\text { nariach i konferen- } \\
\text { cjach naukowych }\end{array}$ & $\begin{array}{l}\text { - duży stopień współ- } \\
\text { pracy z instytucjami } \\
\text { naukowo-badaw- } \\
\text { czymi, klientami } \\
\text { i dostawcami } \\
\text { - podmioty sieci } \\
\text { w dużym stopniu } \\
\text { uczestniczą w semi- } \\
\text { nariach i konferen- } \\
\text { cjach naukowych }\end{array}$ & $\begin{array}{l}\text { - bardzo duży stopień } \\
\text { współpracy z insty- } \\
\text { tucjami naukowo- } \\
\text {-badawczymi, klien- } \\
\text { tami i dostawcami } \\
\text { - podmioty sieci } \\
\text { w bardzo dużym } \\
\text { stopniu uczestni- } \\
\text { czą w seminariach } \\
\text { i konferencjach } \\
\text { naukowych }\end{array}$ \\
\hline
\end{tabular}


badaniach wynosi ona 72. Wartość ta zostałaby osiągnięta przez klaster, jeżeli otrzymałby ocenę 4 dla każdego z kryteriów oceny. Następnie przeprowadza się kategoryzację indeksu IWI poprzez przełożenie wartości indeksu kwalifikacji punktowej IWI na określoną kategorię (tab. 3).

Tabela 3. Klastry zakwalifikowane do poszczególnych przedziatów hierarchicznych indeksu IWI

\begin{tabular}{|l|c|c|}
\hline \multicolumn{1}{|c|}{ Kategoria } & Punktacja & $\begin{array}{c}\text { Liczba } \\
\text { klastrów }\end{array}$ \\
\hline $\begin{array}{l}\text { Kategoria 1 - sieć o wysokim } \\
\text { indeksie IWI: powyżej 80\% } \\
\text { wielkości maksymalnej }\end{array}$ & $57-72$ & - \\
\hline $\begin{array}{l}\text { Kategoria 2 - sieć } \\
\text { o zadowalającym indeksie IWI: } \\
\text { 61-80\% wielkości maksymalnej }\end{array}$ & $45-56$ & 22 \\
\hline $\begin{array}{l}\text { Kategoria 3 - sieć o przeciętnym } \\
\text { indeksie IWI: } 40-60 \% \text { wielkości } \\
\text { maksymalnej }\end{array}$ & $28-44$ & 33 \\
\hline $\begin{array}{l}\text { Kategoria 4 - sieć o niskim } \\
\text { indeksie IWI: od } 40 \% \text { wielkości } \\
\text { maksymalnej }\end{array}$ & $0-27$ & 8 \\
\hline
\end{tabular}

\section{Źródło: opracowanie własne}

Kategoryzacja pozwoliła podzielić badane klastry na te, które mają wysoki, zadowalający lub przeciętny i niski indeks efektywności. Końcowym etapem postępowania jest sformułowanie ustaleń diagnostycznych i interpretacja wyników badań.

\section{Podsumowanie}

W ychodząc z założenia, iż ocena potencjału wiedzy i innowacji sieci międzyorganizacyjnych wymaga wieloaspektowego podejścia, odzwierciedlającego złożoność relacji w nich zachodzących, przedstawiono autorską koncepcję oceny potencjału wiedzy i innowacyjności sieci międzyorganizacyjnych ze szczególnym uwzględnieniem kryteriów i wzorców tej oceny. Użyteczność praktyczna propozycji wiąże się z możliwością wykorzystania zaproponowanej koncepcji w ocenie różnorodnego rodzaju sieci międzyorganizacyjnych, co umożliwi formułowanie ustaleń diagnostycznych oraz przeprowadzenie analizy przyczynowej, badań porównawczych, dynamicznych i przestrzennych.

Na podstawie przeprowadzonych badań można sformułować implikacje dla teorii i praktyki:

- przeprowadzone analizy pozwoliły na zaprezentowanie narzędzia badawczego $\mathrm{z}$ zestawem miar pozwalających na ocenę potencjału wiedzy i innowacyjności sieci międzyorganizacyjnych. W pomiarze tym, poza materialnymi efektami sieci, konieczne jest także uwzględnienie efektów mających charakter niematerialny;

- problemem może być wybór zestawu miar, które moga być przydatne $\mathrm{w}$ ocenie potencjału wiedzy i innowacyjności sieci. Zaproponowane kryteria wykorzystują percepcję uczestników sieci, co sprawia, że są możliwe do zastosowania nawet mimo braku danych obiektywnych;

- ocena potencjału wiedzy i innowacyjności może być różna wśród grup interesariuszy;

- duża część czynników istotnie wpływających na potencjał wiedzy i innowacyjności ma trudno mierzalny czy też niekwantyfikowany charakter, co utrudnia precyzyjną analizę i ocenę tej problematyki;

- dodatkowym problemem jest słabość systemów monitorowania potencjału innowacyjnego na poziomie regionu, co skutkuje złą dostępnością, jakością i ilością danych.

Zaprezentowana metoda może stanowić wstęp do dalszych analiz i badań porównawczych. Wyłonione klastry w poszczególnych kategoriach można poddać analizie relacji w ramach klastra, a w dalszej kolejności badaniu przepływów wiedzy. Do analizy przepływów wiedzy wykorzystuje się najczęściej metodę mapowania i instrumenty analizy sieci społecznych (Social Network Analysis - SNA). Takie, bardziej szczegółowe, badania pozwoliłyby na porównanie klastrów w poszczególnych kategoriach i udzielenie odpowiedzi na pytanie o przyczyny niższych wartości indeksu IWI.

\section{dr hab. Beata Barczak, prof. uczelni Uniwersytet Ekonomiczny w Krakowie Kolegium Nauk o Zarządzaniu i Jakości ORCID: 0000-0003-0345-2267 e-mail: barczakb@uek.krakow.pl}

\section{Przypis}

1) Publikacja została sfinansowana ze środków przyznanych Wydziałowi Zarządzania Uniwersytetu Ekonomicznego w Krakowie, w ramach dotacji na utrzymanie potencjału badawczego w roku 2019.

\section{Bibliografia}

[1] Adams R., Jeanrenaud S., Bessant J., Denyer D., Overy P. (2016), Sustainability-oriented Innovation: A Systematic Review, „International Journal of Management Reviews”, Vol. 18, No. 2, pp. 180-205.

[2] Anthony S.D. (2010), Przez innowację do wzrostu. Jak wprowadzić innowacje przełomowa, Wolters Kluwer, Warszawa.

[3] Barczak B. (2016). Koncepcja oceny efektywności struktur sieciowych, Wydawnictwo Uniwersytetu Ekonomicznego w Krakowie, Kraków.

[4] Bojewska B. (red.), (2013), Innowacyjność organizacji sieciowych $w$ gospodarce opartej na wiedzy, Szkoła Główna Handlowa - Oficyna Wydawnicza, Warszawa.

[5] de Man A.P., Duyers G. (2005), Collaboration and Innovation: A Reveiw of the Effects of Mergers, Acquisitions and Alliances on Innovation, „Technovation”, Vol. 25, No. 12, pp. 1377-1387.

[6] Doeringer P.B., Terkla, D.G. (1995), Business Strategy and Cross-industry Clusters, „Economic Development Quarterly", Vol. 9, No. 3, pp. 225-237. 
[7] Garncarczyk J. (2014), Klaster jako otoczenie przedsiębiorczości strategicznej, [w:] Przedsiębiorczość i innowacje - analiza systemowa sooipp Annual 2014, Zeszyty Naukowe Uniwersytetu Szczecińskiego, Nr 796, s. 75-88.

[8] Gomes-Casseres B. (1996), The Alliance Revolution. The New Shape of Business Rivarly, Harvard University Press, Cambridge.

[9] Gordon I.R., McCann P. (2005), Innovation, Agglomeration and Regional Development, "Journal of Economic Geography”, Vol. 5, No. 5, pp. 523-543.

[10] Guzik R. (2004), Przestrzenne zróżnicowanie potencjału innowacyjnego $w$ Polsce, [w:] M. Górzyński, R. Woodward (red.) Innowacyjność polskiej gospodarki, „Zeszyty Innowacyjne 2", CASE, Warszawa, s. 33-36.

[11] Iammarino S., McCann P. (2006), The Structure and Evolution of Industrial Clusters: Transactions, Technology and Knowledge Spillovers, „Research Policy”, Vol. 35, No. 7, pp. 1018-1036.

[12] Jacobs D., De Man A.P. (1996), Cluster Industrial Policy and Firm Strategy: A Menu Approach, „Technology Analysis and Strategic Management", Vol. 8, No. 4, pp. 425-438.

[13] Jasiński A.H., Głodek P., Jurczyk-Bunkowska M. (2019), Organizacja $i$ zarządzanie procesami innowacyjnymi, Polskie Wydawnictwo Ekonomiczne, Warszawa.

[14] Jasiński A.H. (2014), Innowacyjność w gospodarce Polski. Modele, bariery, instrumenty wsparcia, Wydawnictwo Wydziału Zarządzania Uniwersytetu Warszawskiego, Warszawa.

[15] Kasperkiewicz W. (red.), (2009), Innowacyjność, konkurencyjność i rynek pracy $w$ procesie transformacji polskiej gospodarki, Wydawnictwo Uniwersytetu Łódzkiego, Łodź.

[16] Kazimierski J. (2012), Rozwój i zarządzanie strukturami klastrowymi $w$ regionie, Wydawnictwo Uniwersytetu Łódzkiego, Łódź.

[17] Knop L. (2011), Kluczowe założenia analizy klastrów, „Organizacja i Zarządzanie”, Nr 4(16), s. 37-63.

[18] McCosh A., Smart A., Barrer P., Lloyd A. (1998), Proven Methods for Innovation Management. An Executive Wish List, „Creativity and Innovation Management”, Vol. 7, No. 4, pp. 175-193.

[19] Moszkowicz K., Bembenek B. (2017), Innowacyjność polskich klastrów - strategiczne wyzwanie w zarządzaniu klastrami, „Organizacja i Kierowanie”, Nr 4, s. 27-45.

[20] Nawrocki T. (2015), Problematyka pomiaru i oceny innowacyjności przedsiębiorstw, CeDeWu, Warszawa.

[21] Nowakowska A. (red.), (2009), Zdolności innowacyjne polskich regionów, Wydawnictwo Uniwersytetu Łódzkiego, Łódź .

[22] OECD (2000), Local Partnership, Cluster and SME Globalisation, Bologna.

[23] Olesiński Z., Rzepka A., Sabat A. (2016), Międzyorganizacyjne sieci współpracy gospodarczej na przykładzie Polski, Kanady i Gruzji, Texter, Warszawa.

[24] Plawgo B. (2014), Benchmarking klastrów w Polsce - edycja 2014. Raport $z$ badania, PARP, Warszawa.

[25] Porter M.E. (2001), Porter o konkurencji, PWE, Warszawa.

[26] Powell W.W., Grodal S. (2006), Network of Innovators, [in:] J. Fagerberg, D.C. Mowery, R.R. Nelson (eds.),
Oxford Handbook of Innovation, Oxford University Press, Oxford, pp. 56-85.

[27] Rosenfeld S.A. (1997), Bringing Business Clusters into the Mainstream of Economic Development, „Euorpean Planning Studes", Vol. 5, No. 1, pp. 3-23.

[28] Schiuma G., Lerro A. (2010), Knowladge-based Dynamics of Regional Development: The Intellectual Capital Innovation Capacity Model, „International Journal of Knowladge-based Development", Vol. 1, No. 1-2, pp. 25-38.

[29] Skawińska E., Zalewski R. I. (2009). Klastry biznesowe $w$ rozwoju konkurencyjności i innowacyjności regionów. Świat - Europa - Polska, PWE, Warszawa.

[30] Sopińska A. (2013), Knowledge Management at Network Organizations, „Organization and Management”, Vol. 154, No. 1, pp. 87-104.

[31] Stabryła A. (2011), Metody oceny agregatowej w podejmowaniu decyzji projektowych, Zeszyty Naukowe MWSE w Tarnowie, Nr 17, s. 235-254.

[32] Stabryła A. (2016), Paradygmat oceny agregatowej $w$ analizie strategicznej, Prace Naukowe Uniwersytetu Ekonomicznego we Wrocławiu, Nr 420, s. 275-285.

[33] Szwabowski J., Deszcz J. (2001), Metody wielokryterialnej analizy porównawczej. Podstawy teoretyczne i przykłady zastosowań $w$ budownictwie, Wydawnictwo Politechniki Śląskiej, Gliwice.

[34] Szymura-Tyc M. (2015), Internacjonalizacja, innowacyjność i usieciowienie przedsiębiorstw. Podejście holistyczne, Difin, Warszawa.

[35] Zhao Y., Zhou W., Huesig S. (2010), Innovation as Clusters in Knowledge Intensive Business Services: Taking ICT Services in Shanghai and Bavaria as an Example, „International Journal of Innovation Management", Vol. 14, No. 1, pp. 1-18.

\section{Assessment of the Potential of Knowledge and Innovation of Inter-organisational Networks in the Light of Polish Clusters' Research}

\section{Summary}

The aim of the article is to develop a concept for analysing and assessing the potential of knowledge and innovation of Polish clusters, with an indication of criteria and assessment patterns. In the theoretical layer, the methods and concepts of innovation potential assessment have been reviewed, the concept of knowledge and innovation potential has been defined, and the specificity of cluster structures has been presented. In the main part of the article its author presents the original method for assessing the innovation potential of clusters in the cross-section of individual criteria and formulates implications for theory and practice.

\section{Keywords}

potential of knowledge and innovation, inter-organizational networks, clusters 